\title{
Chronic Hepatitis C and Health-Related Quality of Life in Patients with Cognitive Impairment
}

\author{
Italo Alvarez Juan C. Urbina Romina A. Tejada \\ School of Medicine, Universidad Peruana de Ciencias Aplicadas (UPC), Lima, Peru
}

\section{Keywords}

Quality of life - Chronic hepatitis C · Cognitive impairment .

Caregivers

\section{Hepatite C crônica e qualidade de vida relacionada à saúde em pacientes com comprometimento cognitive}

\section{Palavras Chave}

Qualidade de vida · Hepatite C crônica .

Comprometimento cognitive $\cdot$ Cuidadores

\section{Dear Editor,}

We have read the article by Rei et al. [1] about healthrelated quality of life valuation in patients with hepatitis $\mathrm{C}$ virus (HCV) infection. While we agree that it contributes to the subject knowledge, we think the selection of patients should be further discussed.

The authors state that the presence of low cognitive level is part of the exclusion criteria. We understand that this criterion is important as it relates to the capacity of patients to answer and value their own health

\section{KARGER}

E-Mail karger@karger.com www.karger.com/pjg (c) 2018 Sociedade Portuguesa de Gastrenterologia
Published by S. Karger AG, Basel Karger
Open access

This article is licensed under the Creative Commons Attribution NonCommercial-NoDerivatives 4.0 International License (CC BYNC-ND) (http://www.karger.com/Services/OpenAccessLicense) Usage and distribution for commercial purposes as well as any distribution of modified material requires written permission. states; however, this leads to a lower representativeness of the study population within the whole population with HCV, especially when considering that cognitive alteration is a usual complication of chronic HCV infection [2]. Therefore, we believe that this population should not be excluded as it is important to consider their health-related quality of life as necessary information for their care and also for developing cost-utility studies.

We propose that the authors could interview caregivers of these patients as a viable alternative. For example, Kahle-Wrobleski et al. [3] have considered the caregiver (person who knows and has contact with the patient at least $10 \mathrm{~h}$ per week) as a good source to valuation of the quality of life in patients with Alzheimer disease or dementia. Sneeuw et al. [4] did a review of 23 studies on health-related quality of life published between 1991 and 2000 and concluded that the coincidence between patient and proxy was moderate to high and the difference of quality of life reported was modest (median of $0.2)$.

We also recommended another option, which would be to develop an instrument for patients with chronic diseases, like HVC infection, and cognitive impairment, 
like the San Martin scale. This instrument is a multidimensional scale to measure quality of life in patients with significant intellectual disabilities through an informant (person who has known the patient and his disease for at least 3 months and has had the opportunity to watch it for extended periods of time) [5].

In conclusion, we suggest that in the case of patients with cognitive impairment, researchers should inter- view the caregiver because this person is a reliable source of information in patients with chronic disease such as $\mathrm{HCV}$ infection.

\section{Disclosure Statement}

The authors have no conflicts of interest to declare.

\section{References}

Letter to the Editor
1 Rei A, Rocha M, Pedroto I: Health-related quality of life in Portuguese patients with chronic hepatitis C. GE Port J Gastroenterol 2017;24:68-78.

2 Iriana S, Curry MP, Afdhal NH: Neurologic manifestations of hepatitis $C$ virus infection. Clin Liver Dis 2017;21:535-542.

3 Kahle-Wrobleski K, Ye W, Henley D, Hake AM, Siemers E, Chen Y-F, et al: Assessing quality of life in Alzheimer's disease: implications for clinical trials. Alzheimers Dement Amst Neth 2017;6:82-90.
4 Sneeuw KCA, Sprangers MAG, Aaronson NK: The role of health care providers and significant others in evaluating the quality of life of patients with chronic disease. J Clin Epidemiol 2002;55:1130-1143.

5 Verdugo MA, Gómez LE, Arias B, Navas P, Schalock RL: Measuring quality of life in people with intellectual and multiple disabilities: validation of the San Martín scale. Res Dev Disabil 2014;35:75-86. 